\title{
PNEUMATIKUS HAJTÁSÚ TANULMÁNYAUTÓ TELEMETRIAI MÉRŐRENDSZERÉNEK KIALAKÍTÁSA
}

\section{DEVELOPMENT OF TELEMETRY MEASURING SYSTEM OF PNEUMATIC DRIVEN CONCEPT VEHICLE}

\author{
Zilahi Krisztián László ${ }^{1}$, Sipos Kristóf Balázs ${ }^{2}$, Tóth Xénia Erzsébet $^{3}$, \\ Lovadi Gyula Dávid ${ }^{4}$ \\ ${ }^{1,2,3}$ Debreceni Egyetem, Müszaki Kar, Villamosmérnöki és Mechatronikai Tanszék, \\ 4028, Magyarország, Debrecen, Ótemetö utca, 2-4, ${ }^{1}$ imkrisztian@mailbox.unideb.hu \\ 2siposk94@gmail.com, ${ }^{3}$ tothxeniaerzs@gmail.com \\ ${ }^{4}$ Debreceni Egyetem, Müszaki Kar, Gépészmérnöki Tanszék, 4028, Magyarország, \\ Debrecen, Ótemetö utca, 2-4, lovadi92@gmail.com
}

\begin{abstract}
In this paper, we introduce a special construction of a telemetry measuring system. The created system can be used for measuring and acquisition different data - meanwhile operation - of a pneumatic engine and dynamic parameters of a pneumatic driven concept vehicle, which was developed by University of Debrecen - Faculty of Engineering. For analyzing our vehicle we use a Programmable Logic Controller (PLC), which processes the signals of the different sensors, moreover with the development environment of National Instruments LabVIEW we created an application for observing the different parameters in real time, and saving them for the further data processing is also possible. To ensure the reliability, we used industrial sensors, actuators and controller units in the system.
\end{abstract}

Keywords: measuring system, telemetry, PLC, HMI, microcontroller, LabVIEW, Modbus TCP.

\section{Összefoglalás}

A tanulmányban egy speciális telemetriai mérőrendszer kialakítását mutatjuk be, mely a Debreceni Egyetem Müszaki Karán fejlesztett pneumatikus hajtású jármü pneumatikus motorjának és dinamikai paramétereinek müködés közbeni mérésére, adatgyüjtésére alkalmas. A jármü vizsgálatához, felhasználtunk egy programozható logikai vezérlőt (PLC-t), mely a különböző szenzorok jeleit dolgozza fel, valamint a National Instruments LabVIEW fejlesztőkörnyezet segítségével elkészítettünk egy alkalmazást, ahol a különböző paraméterek valósidejü megfigyelésére, valamint azok mentésére is van lehetőség, a későbbi adatfeldolgozáshoz. A megbízhatóság érdekében a berendezés érzékelö, végrehajtó és vezérlő egységei, ipari eszközök segítségével kerültek kialakításra.

Kulcsszavak: mérörendszer, telemetria, PLC, HMI, mikro vezérlö, LabVIEW, Modbus TCP.

\section{Bevezetés, előzmények}

A dolgozat alapjául a Debreceni Egyetem Müszaki Karán fejlesztett pneumatikus hajtású jármű szolgál (1. ábra). A pneumobil egy sürített levegővel müködö jármü, amely a sürített közeg energiáját alkalmazva pneumatikus eszközök segítségével adja át a nyomatékot a hajtott kerékre, és egy pilótával a fedélzetén kell teljesítenie a versenyszámokat. 


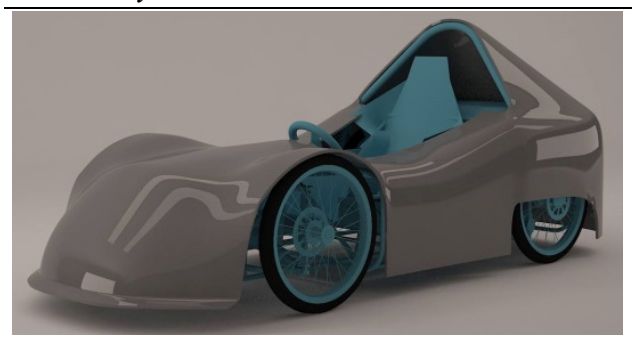

1. ábra. A pneumatikus hajtású tanulmányautó

A tervezés megalapozásának szempontjából fontos a korábbi eredmények kiértékelése, és a lehetséges megoldások vizsgálata.

A rendelkezésre álló statisztikai adatok alapján megállapítható, hogy általában a legeredményesebb pneumobilok PLC vezérlésűek, és motoruk alternáló felépítésü, szerkezeti kialakítását tekintve két kormányzott kerékkel rendelkeznek, és hátsókerék meghajtásúak.

\section{Mérendő paraméterek meghatá- rozása}

A jármünek adott versenykörülményeknek kell megfelelnie, melyhez terveztünk egy alapmodellt, melyet megfelelő dinamikai szempontok szerint méreteztünk. Az így kapott modell dinamikai paramétereit kell vizsgálnunk ahhoz, hogy a jármü menetdinamikáját javítani tudjuk, akár mechanikai paraméterek változtatásával, akár a jármü vezérlésének optimalizálásával.

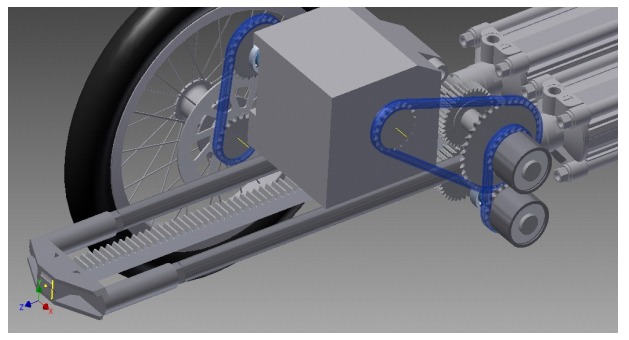

2. ábra. A pneumatikus motor

Ehhez vizsgálnunk kell a légmotor (2. ábra) tulajdonságait, ezen belül a motor karakterisztikáját, így a mért adatokból származtatjuk a nyomaték-idő függvényt, a levegő felhasználást, a jármü sebességét, a gyorsulását, az általa megtett utat, valamint a menet közbeni GPS koordinátákat.

\subsection{Pneumatikus hajtáslánc tulajdon- ságai}

A hajtáslánc optimalizálása érdekében szükségünk van az abban ténylegesen létrejövő dinamikai paraméterekre. Ezen paramétereket méréssel, illetve a mért adatokból való származtatással tudjuk megállapítani.

A dinamikai egyenlet felírásakor a gáz állapotváltozásaiból adódó hatásokat a $\sum F_{S A}, \sum F_{S B}$ tényezőkben vettük figyelembe.

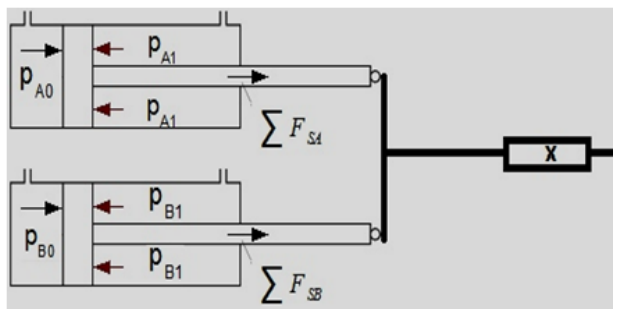

3. ábra. A hengerek húzóerejének származtatása

A henger húzóerejének származtatása a 3. ábrán látható.

$p_{A 1}$ : 'A' munkahenger töltőnyomása

$p_{B 1}$ : 'B' munkahenger töltőnyomása

$p_{A 0}$ : 'A' munkahengerből kiáramló levegő nyomása

$p_{B 0}$ : 'B' munkahengerből kiáramló levegö nyomása

$A$ hengerfejekre ható erö nagysága:

$F_{A}(t)=p_{A 1}(t) \cdot A_{2}-p_{A o}(t) \cdot A_{1}-$

$\sum F_{S A}\left(T_{k}, t, v\right)$

$F_{B}(t)=p_{B 1}(t) \cdot A_{2}-p_{B o}(t) \cdot A_{1}-$

$\sum F_{s B}\left(T_{k}, t, v\right)$

\subsection{A jármű menetdinamikai paramé- terei}

A jármü dinamikai tulajdonságaira vonatkozó adatok gyüjtése egy gyorsulásmérővel, valamint GPS-el ellátott Android operációs rendszerü mobiltelefonnal történik, itt a telefon memóriájára tárolódnak a mért adatok, melyet csak utólag tudunk majd kiértékelni. 
A számított dinamikai adatokból, valamint a jármü tömegéből meghatározzuk a jármü menetteljesítményét a levegőfogyasztás függvényében:

$$
\begin{aligned}
& \sum F(t)=m \cdot a(t) \\
& P_{\text {menet }}(t)=F(t) \cdot v(t)
\end{aligned}
$$

A mérés célja az adott pneumatikai teljesítményhez tartozó legjobb mechanikai teljesítmény meghatározása, vagyis a legjobb hatásfok megkeresése.

\section{A mérésadatgyűjtő rendszer fel- építése}

\subsection{A programozható logikai vezérlő}

A Programozható Logikai Vezérlő (PLC) az elektromos vezérlésü szelepek irányítását és a jármüvön elhelyezett szenzorok adatainak feldolgozását végzi. A program egy memóriakártyán van tárolva, mely a megvalósítandó feladatokhoz szabadon változtatható. Az IndraControl L10-es vezérlőegység az ún. Microvezérlők csoportjába tartozik [1].

\subsection{A LabVIEW alkalmazás}

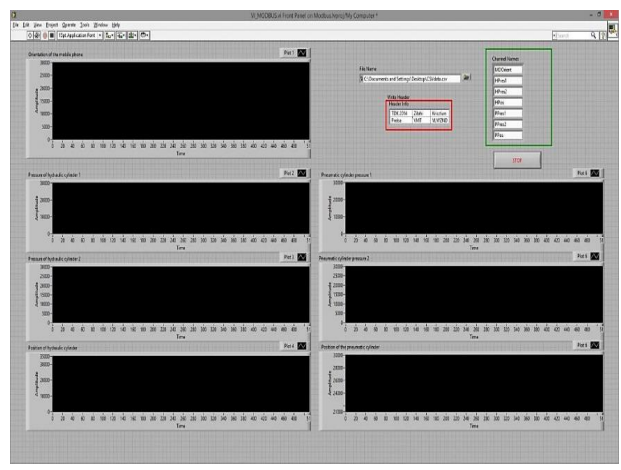

4. ábra. Az elkészitett LabVIEW alkalmazás

Az alkalmazás biztosítja (4. ábra) a különböző beállítások valósidejü megfigyelésére szolgáló adatok grafikonon történő megjelenítését, a rendszer paramétereinek és különböző adatainak mentését a későbbi kiértékelésére, ezzel egy a rendszerre illesztett mérörendszert hoztunk létre.

\subsection{A felhasznált szenzorok}

A mérőrendszer kialakításánál feltételezzük a pneumatikus hajtórendszer szimmetrikus müködését, ezért csak az egyik hengerre helyezünk el szenzorokat.

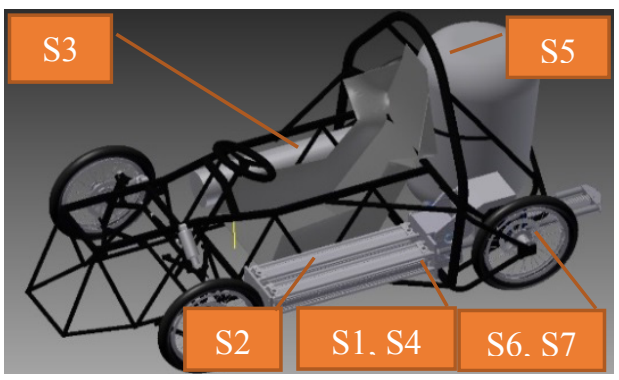

5. ábra. A szenzorok elhelyezése a jármüvön

A méréshez felhasznált eszközök, melyek elhelyezése a $\mathbf{5}$. ábrán látható:

- Tacho méter: (S6, S7);

- Útadó szenzor: SM6 (S2);

- Nyomásszenzor: PE5 (S1);

- Áramlásszenzor: AF1 (S3);

- Kiegészítő bemeneti analóg modulok a PCL-hez:

- Rádiós adattovábbító eszközök;

- Hőmérő szenzorok:

- a környezet hömérséklete (S4);

- a sürített levegő hőmérséklete (S5);

- Gyorsulási és GPS (pályakoordináta és pillanatnyi sebesség) adatok gyüjtésére: gyorsulás mérővel és GPS-el ellátott Android operációs rendszerü mobiltelefon.

\subsection{A fedélzeti kijelző}

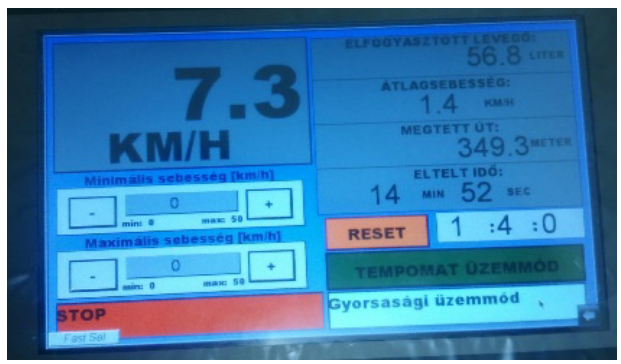

6. ábra. A HMI megjelenítö felülete 
A pilóta számára elhelyezett nyomásra érzékeny (rezisztív) érintőpaneles vezérlöegységre (HMI) (6. ábra) elkészítettünk egy grafikus felületet, melyen a pilóta figyelemmel kísérheti a fontosabb menet közbeni információkat, valamit ennek segítségével aktiválhat különböző üzemmódokat, és megadhat azokhoz tartozó paramétereket [2].

\section{A rendszeren belüli kommuni- káció}

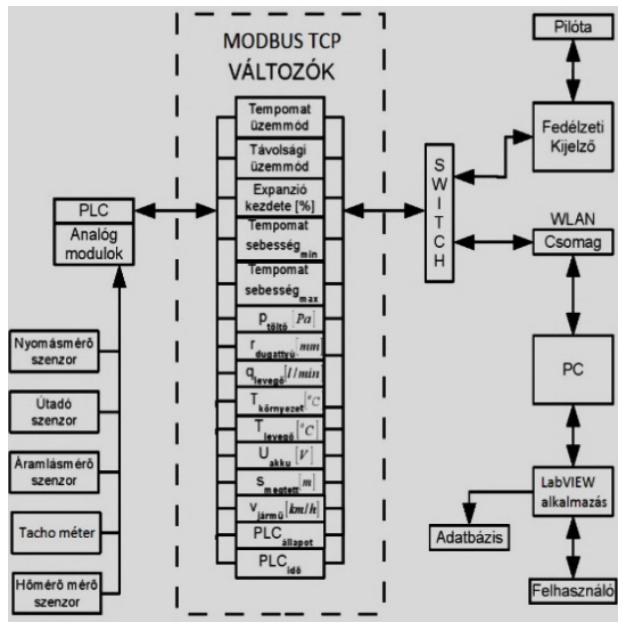

7. ábra. $A$ rendszeren belüli kommunikáció funkcióblokkos vázlata

A rendszeren belüli kommunikáció (7. ábra) egy ETHERNET alapú úgynevezett Modbus TCP/IP ipari kommunikációs protokollon keresztül történik.

A hálózaton belül a PLC tölti be a Modbus Szerver (Slave) szerepét, így generál egy valós idejủ adatbázist. A valós idejü adatbázis jelen esetben azt jelenti, hogy a változók értékei kevesebb, mint 10-20 milliszekundumonként frissülnek. Ez a felhasznált eszközök feldolgozási sebességéhez mérten elegendő ahhoz, hogy valós idejünek tekinthető legyen a rendszer. Az adatbázisban szereplő megfelelő változók értékeinek beírását, valamint olvasását a PLC is végezheti vagy a PC-n futó LabVIEW alkalmazás. A LabVIEW és a mobil eszköz, mint Modbus Kliens (Master) tud csatlakozni a szerverhez. A kommunikáció létrejöttéhez legalább egy Modbus Slave és egy Modbus Masterre van szükség [3].

\section{5. Összegzés, következtetések}

A rendszer két fö elemből áll: a jármüre telepített IndraControl L10 típusú PLC, PC alapú mérésadatgyüjtő alkalmazás, amelyet a NI LabVIEW fejlesztőkörnyezetében hoztunk létre.

A fejlesztés során a hajtás felépítését vizsgáltuk mérési szempontok szerint. Azután a mért fizikai jellemzők jeleit vizsgáltuk programozási szempontból, továbbá elvégeztük a gépjármü és a hajtás dinamikai vizsgálatát méréstechnikai szempontból.

Megválasztottuk a müszaki specifikációt kielégítő méréstechnikát, a hozzá tartozó szenzorokat és mérőeszközöket, továbbá elvégeztük ezen eszközök jellemzését. Kifejlesztettük a mérési metódust megvalósító PLC programot.

Elkészítettük pneumatikus hajtás egyszerüsített modelljét és az ahhoz kiépített telemetriai mérörendszert az egyetemen elérhető eszközökből, melyet videó formájában dokumentáltunk [4].

\section{Szakirodalmi hivatkozások}

[1] Karl Heinz John, Michael Tiegelkamp: IEC 61131-3: Programming Industrial Automation Systems, kiadó: Springer, London, 2010. 400 p. ISBN szám: 9783642120145

[2] Ajtonyi István: PLC és SCADA-HMI rendszerek I. 1. kötet. PLC programozás az IEC 61131-3 szabvány szerint, kiadó: AUTINFO Kiadó Miskolc, 2007. 290 p. ISBN szám: 9789630631655

[3] Ajtonyi István: Ipari kommunikációs rendszerek I. 1. kötet. kiadó: AUT-INFO Kiadó, Miskolc, 2008. 431 p. ISBN szám: 9789630658133

[4] A rendszer müködése, videó: https://www.youtube.com/watch?v=YdVpyxenNk Megtekintve: 2016. 02. 01. 